\title{
Ecological Risk Assessment of Agricultural Pesticides throughout the Shadegan Wetland, Iran
}

\author{
Fatemeh Karimi (Corresponding author) \& Faramarz Moattar, Parvin Farshchi \\ Department of Environment and Energy, Science and Research Branch, Islamic Azad University, Tehran, Iran \\ Tel: 98-611-372-7174 E-mail: fatemeh_karimi88@yahoo.com
}

\author{
Ahmad Savari \\ Department of Marine Biology, Faculty of Marine Science \\ Marine Science and Technology University, Khoramshahr, Iran
}

Hooshang Parham

Department of Chemistry, College of Science, Shahid Chamran University, Ahvaz, Iran

Received: November 16, 2011

Accepted: December 1, $2012 \quad$ Online Published: April 1, 2012

doi:10.5539/jas.v4n5p109

URL: http://dx.doi.org/10.5539/jas.v4n5p109

\begin{abstract}
As a major ecosystem type, wetland provides invaluable ecological services. Environmental pollution, especially pesticide runoffs should be paid more attention to keep wetlands healthy. This paper proposes two methodologies namely, deterministic and probabilistic approaches. Deterministic approach or risk quotient (RQ) was calculated using the water concentration and toxicant reference values of five pesticides (DDT, Aldrine, Dieldrin, Ametryn, Lindane). For probabilistic approach, hazardous concentrations for $5 \%$ of species $\left(\mathrm{HC}_{5}\right)$ were estimated. The results of deterministic approach showed that the RQ for shirbot or large scaled barb (Barbus grypus), benni (Barbus sharpeyi), golden barb (Barbus luteus) and insect larvae (Chironomus sp.) is high and the environment is exposed to higher risk. However, the results of probabilistic approach and $\mathrm{HC}_{5}$ showed that DDT and Lindane are the most harmful pesticides and can create unsuitable environment. It is recommended that proper countermeasures should be implemented to reduce the risks.
\end{abstract}

Keywords: Ecological Risk Assessment, Agricultural Pesticide, Shadegan Wetland, Iran

\section{Introduction}

Shadegan wetland comprises the southern portion of the extensive flood plain and delta systems of the Karun, Dez and several other major rivers which rise in the northwest zagros mountains of western Iran. The sugarcane agro-industrial units have established north western the fresh water marsh. On average more than 30 thousand tons of fertilizers and 100 tons of pesticides are annually used within the catchments area (Lotfi et al., 2002). Different studies have been carried out in shadegan wetland to assess the pedological, climatological, hydrological, biological and ecological parameters (Fisheries Research Center, 1996; Lotfi et al., 2002). Survey of the chemical pesticides in the aquatic species of shadegan wetland indicates different level of residues (Arzi et al., 1999; Davodi et al., 2010; Arzi, A, 2010). For instance, (Davodi et al., 2010) showed that in all samples of fishes organochlorine pesticides were found higher concentrations than polychlorinated biphenyls (PCBs), But ecological risk assessment studies has not done in this case. There is growing urgency to assess the ecological risk in shadegan wetland. For most risk assessments, EPA uses deterministic approach or the risk quotient method to compare toxicity to environmental exposure (U.S.EPA, 1998).In probabilistic assessment, ecological risk is expressed as the degree of overlap between the distribution of environmental exposure concentration and distribution of toxicity values. Therefore, the objective of the present study is to assess the ecological risk assessment using deterministic and probabilistic approaches in shadegan wetland. 


\section{Material and Methods}

\subsection{Study Area}

Shadgan wetland is located in $30^{\wedge} 20^{\prime} \mathrm{N}$ and $48^{\wedge} 20^{\prime} \mathrm{E}$, in the southwestern part of Iran in Khuzestan province, surrounded by cities such as Abadan, Shadegan and Mahshahr (Fig.1). The region is characterized by its extremely high temperatures, with mean July temperatures in excess of $45^{\wedge} \mathrm{c}$ and mean January temperatures in excess $7^{\wedge} \mathrm{c}$. The average annual rainfall is $146 \mathrm{~mm}, 22 \%$ of which falls as winter precipitation, with an abrupt onset in November and more gradual termination in April or May. Shadegan wetland according to Ramsar convention is an international wetland covers almost 400000 ha about 296000 ha were established as a wildlife refuge that surrounds the main wetland area. Major point sources of contamination in this area includes fertilizers, herbicides and pesticides of sugarcane plant and agricultural lands in northwestern of freshwater marsh and non-point sources consist of hazardous substances particles from refineries and Mahshahr, Bandar imam and Abadan chemical and petrochemical factories (Davodi et al., 2010). Shadegan wetland possesses different ecosystems, especially, fresh, brackish and salt waters. For estimation of ecological risk assessment; the environmental effect concentration (EEC) of 5 pesticides (DDT, Aldrin, Dieldrin, Lindane and Ametryn) was measured at 5 compartments from fresh and salt waters. These pesticides were chosen as target analytes on the basis of being included usage sugarcane industry in region and their application in study area. It seems that even though the use of organochlorine pesticides has been banned in Iran since 1983, this trend is applicable (Coke et al., 1999; Hosseini et al., 2008). Selection of compartments has been done basis current, salinity of water and bed topography. The first three compartments are located in the proximity of the sugarcane outfalls and the last two away from the outfalls along their axes. All of them serve as compartments (Fig.2).

\subsection{Sample Collection}

Water sampling was performed on a seasonally basis (spring, summer, autumn, 2010) at five sampling compartments. Three replicates samples were taken from middepth $(0.5 \mathrm{~m})$ using water bottle (Table 1). Samples were stored at $4 \wedge \mathrm{c}$ until the analysis, which was performed maximum within $48 \mathrm{~h}$. All sample collection was done according to quality control (QC) and quality assurance (QA) standards.

\subsection{Sample Analysis}

The analysis of pesticides in water samples were based on the solid-phase micro extraction procedures described in (Hela et al., 2002). Ten (10) $\mathrm{ml}$ volume of water samples was placed in $20 \mathrm{ml}$ vials, sealed with hole-caps and PTFE line septa. The samples were stirred at room temperature $\left(25+2{ }^{\wedge} \mathrm{c}\right)$. After extraction, the fibre was directly exposed to the hot injector of the GC systems for analysis. Thermal desorption of pesticides was carried out for $10 \mathrm{~min}$. After this period no significant blank values were observed. The quantification was carried out by peak area using the external standard calibration. A detailed description of the methods is given elsewhere (Hela et al., 1998; Hela et al., 2005).

\subsection{Measurement of Ecological Risk Assessment}

Calculation of the ecological risk was based on the following two step methodology:

\subsubsection{Risk Quotient Method (RQ)}

In the deterministic approach, RQ is quotient of measured or estimated environmental concentration (exposure) divided by a toxicant reference values (TRV) the RQ single pesticide (i) was calculated using:

$$
\left(\mathrm{RQ}_{\mathrm{i}}\right)=\text { EXPOSURE } / \text { TOXICITY }=\mathrm{MEC}_{\mathrm{i}} / \mathrm{TRV}_{\mathrm{i}}=\mathrm{MEC}_{\mathrm{i}} / \mathrm{LC}_{50} \text { or } \mathrm{EC}_{50}
$$

Where, $\mathrm{MEC}_{\mathrm{i}}=$ measured environmental concentration of pesticide $\mathrm{i}$ (or EEC estimated in field sampling)

$\mathrm{TRV}_{\mathrm{i}}=$ toxic reference values or $\mathrm{LC}_{50}$ or $\mathrm{EC}_{50}$

( $\mathrm{LC}_{50}$-half lethal concentration for the $50 \%$ of the population of tested species) of pesticide (i)

$\mathrm{LC}_{50}$ or $\mathrm{EC}_{50}$ was estimated quantitatively from pesticide action network (PAN) pesticide database or (Mun et al., 2001; Hela et al., 2005; Davodi et al., 2010).

For a mixture of $(n)$ kinds of pesticides, the risk quotient of mixture $\left(\mathrm{RQ}_{\mathrm{m}}\right)$ was calculated as the addition of $\mathrm{RQ}_{\mathrm{i}}$

For mixture components:

\subsubsection{Probabilistic risk assessment}

$$
\mathrm{RQ}_{\mathrm{m}}=\sum_{\mathrm{i}=1}{ }^{\mathrm{n}} \mathrm{RQi}=\sum_{\mathrm{i}=1}{ }^{\mathrm{n}} \mathrm{MEC}_{\mathrm{i}} / \mathrm{TRV}_{\mathrm{i}}
$$

This method provides quantitative estimations of ecological risk based on relevant single-species toxicity data and exposure distributions (Solomon and Sibly, 2002; Hela et al., 2005).On the basis of assumption that the 
frequency distribution of different species effect end points is log-logistic the adverse method of van Strallen and Denneman (Van Strallen and Denneman, 1989) was applied for this study. The mean and the standard deviation of the in-transformed dataset of a number of toxicity end points $\left(\mathrm{LC}_{50}\right.$ or $\left.\mathrm{EC}_{50}\right)$ of a specific pesticide were used to estimate the parameters which describe the distribution. From this distribution, in order to protect $95 \%$ of species, the hazardous concentration for $5 \%$ of the species $\left(\mathrm{HC}_{5}\right)$ in an ecosystem was calculated using the following model based on species sensitivity distributions (Aldenberg and Slob, 1993; Steen et al., 1999; Wang et al., 2008).

$$
\mathrm{HC}_{5}=\exp \left(\mathrm{x}_{\mathrm{m}}-\mathrm{k}_{\mathrm{L}} \mathrm{S}_{\mathrm{m}}\right)
$$

Where, $\mathrm{m}=$ is the number of test species (Table 2, 3) for estimation of toxicant reference values

$\mathrm{X}_{\mathrm{m}}=$ represents the mean of the in-transformed effect levels $\left(\mathrm{LC}_{50}\right.$ or $\left.\mathrm{EC}_{50}\right)($ Table 2,3$)$ (mean of addition of log $\mathrm{LC}_{50}$ or $\mathrm{EC}_{50}$ )

$\mathrm{S}_{\mathrm{m}}=$ standard deviation of the in-transformed effect levels

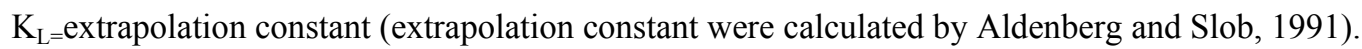

In the basis of importance and knowledge development selected valuable species inhabiting shadegan wetland, this study has been done. Selected species in this study include: generally Green algae and Blue Green algae for phytoplankton, Daphnia pulex in zooplankton category. Oligochaeta and Tubifex tubifex (invertebrates), (Chironomus sp.) in insect category and Barbus grypus, Barbus sharpeyi and Barbus luteus were selected in fish category. Most data were obtained from the pesticide action network (PAN) pesticide database (www.pesticideinfo.org), pesticide toxicity index for fresh water aquatic organisms (Munn et al., 2001) and others were from literature validated toxicological data (Hela et al., 2005; Davodi et al., 2010). Toxicant reference values of different selected species in shadegan wetland are presented in Table 2.

Relying on the risk quotient method in screening level assessments, representative species these at risk and each pesticide for the total ecological risk and each pesticide contribution can be determined. Thus, ecological risk posed by a certain pesticide to the ecosystem is defined by Ecological Risk Quotient (ERQ) calculated by a new model shown in Eq. (4).

\section{Results and Discussion}

$$
\mathrm{ERQ}=\mathrm{MEC} / \mathrm{HC}_{5}=\mathrm{MEC} / \exp \left(\mathrm{x}_{\mathrm{m}}-\mathrm{k}_{\mathrm{L}} \mathrm{s}_{\mathrm{m}}\right)
$$

\subsection{Deterministic Approach Results (RQ)}

The Risk Quotients were calculated by dividing the environmental concentration in Table 1 and the toxicant values in Table 2 using Eq.(1). The sum of Risk Quotients of each detected pesticide is shown in Fig. 3.

The risk quotients of the representative species in Shadegan wetland ranges from 0.06 to 3.40. Comparing to literature reported levels of concern (i.e., $\mathrm{RQ} \geq 1$ high risk, $0.1 \leq \mathrm{RQ} \leq 1$ medium risk, $0.01 \leq \mathrm{RQ} \leq 0.1$ low risk) (Sanchez-Bayo et al., 2002). It is clear that pesticide pose higher risk to lower creatures, and lower risk to higher animals. The total ecological risk of (Chironomus sp.) and B. grypus is highest in the wetland ecosystem, whereas risks of phytoplanktons are low risk level. As a result, insect larves and (Barbus sp.) should be chosen as the key protection objectives of the ecosystem in Shadegan wetland. The relative contributions of pesticides to the total ecological risk were calculated to identify pesticides that pose higher risk to a specific organism (as shown in Fig. 4). Lindane, Aldrin and Dieldrin are the greatest hazards to the species in the wetland. In general, phytoplanktons (algae and blue-green algae) are exposed in Lindane (82\%) and Dieldrin (93\%), sequencely. Risk posed to algae and blue green algae are almost caused by Lindane and Dieldrin, which act strongly on photosynthesis, an important biochemical process in algae. Green algae account for a significant portion of (barbus sp.) diet, because of the food chain effects. For oligochaeta, T. tubifex, (Chironomus sp.), B. sharpeyi and B. luteus, the highest risks are posed by Lindane, whereas toxicity for D. pulex and B. grypus is mainly determined by Aldrin. It seems that Lindane and Aldrin are common pesticides in Shadegan wetland. As a result, in order to protect the ecosystem of Shadegan wetland, there is need to focus on the contaminations of Lindane and Aldrin.

\subsection{Probabilistic Approach Results}

To assess, the combined ecological risk of the detected pesticides, the toxicity data used in this study was found to fit a good log-logistic distribution. Summery of $\mathrm{HC}_{5}$ values of the confidence-level (as shown in Table 3 ) were calculated by Eq. (3). They range from 0.1665 to $59 / 07 \mu \mathrm{g} / \mathrm{L}$. It is clear that DDT has the lowest $\mathrm{HC}_{5} \mathrm{value}$ and may induce potential ecological risk with high probability. In order to provide the contribution of individual 
pesticides to the combine ecological risk quotients were calculated using $\mathrm{HC}_{5}$ values as through Eq.(4). The results were shown in Fig. 5.

For each pesticides in the wetland, the average risk quotient is lower than 1. Among these detected pesticides, DDT has the highest risk quotient, due to use in agriculture probably, high concentration in the water environment and a relatively low $\mathrm{HC}_{5}$ values. Also in November, 2010, risk quotient of DDT exceeds the criterion level, causing an unacceptable ecological risk. Risk quotients of other pesticides such as (Aldrin, Dieldrin and Ametryn), are much lower than the criterion and are safe at Shadegan wetland. As to be expected, higher concentration of pesticides such as DDT and Lindane are found in November, 2010. Large amount of these pesticides enter the water through agricultural runoffs. Lindane is another pesticide which has risk quotients (0.8) in November, 2010. Other pesticides such as Ametryn, Aldrin and Dieldrin have lower Risk Quotient in May, 2010. Concentration of these pesticides depends on the volume of agricultural wastewater. Fig. 6 shows the temporal variations of each pesticide contributions to the combined ecological risk. It can be seen that DDT cause the accounting for $45 \%$ of the combined ecological risk in average. Lindane and Aldrin account for $22 \%$ and $17 \%$ in average respectively.

Temporal changes are shown in May, 2010, September, 2010, November, 2010 in Lindane and Aldrin. In a word, DDT, Lindane and Aldrin contribute most to the ecological risk of the ecosystem, and risk control measures should be taken according to this analysis. In view of the additional effects of the detected pesticides as determined by the RQ method and $\mathrm{HC}_{5}$, it can be concluded that the detected pesticide levels exert a significance pressure on the shadegan wetland especially for the acute effect level. Comparing this study with other studies (C.S QA et al., 2010) showed that both studies consists of similar species (phytoplankton, zooplankton, benthos, fish and insect larvae), both studies have done in wetland ecosystem and Lindane and DDT are noticeable in these studies, but results of RQ method in shadegan wetland for B. sharpeyi, B. luteus, B. grypus and (Chironomus sp.) has been greater important. First, $\mathrm{RQ}$ in (Chironomus sp.) is high level $(\mathrm{RQ}=3.40)$, then other fishes, but in studies of (C.S QA et al., 2010), RQ quantity is lower (RQ=0.9). Therefore, it seems exceptional prevail it would damage the ecosystems and harm the unique biodiversity of the wetland.

\section{Conclusions}

Agricultural wastewater in Shadegan wetland has degraded the quality of water and the functioning of some organisms. This study proposed a methodology by integrating risk quotient and probabilistic risk assessment method. The risks of 5 pesticides in Shadegan wetland were assessed. The assessment indicated that, DDT is the primary pesticide affecting the quality of water in the wetland. DDT causes the most ecological risk to the entire ecosystem, accounting for $45 \%$, followed by Lindane and Aldrin. (Chironomus sp.) And B. grypus are the primary species at risk. The worst water quality occurs in November 2010.

Therefore, it seems that the international wetland is suffering from high load of pesticides in wetland. The results of this study can contribute to the risk management and the restoration efforts that have been conducted during the last years on the wetland by the local authorities. A more complete assessment of the risks posed to the ecosystem of Shadegan wetland will require, in addition to data on the concentrations of pesticides, a more complete set of toxicological information especially for endemic species and for the chronic- effect level. Finally, it is necessary to obtain more environmental data that represent temporal and spatial variations to characterize the total ecological risk of the whole Shadegan wetland ecosystem.

\section{Acknowledgements}

This work is supported by Department of Environment (DOE), South Aquaculture Center in Khuzestan Province and Medical Plant Center in Tehran, IRAN. The authors would also like to thanks all experts in organizations for cooperation's.

\section{References}

Arzi, A. (1999). Identification and determination quality of 14 organochlorine pesticides in some catch fishes in 5 khuzestan catchment region, development of medical science ahvaz.

Arzi, A., Hemmati A. A., \& Nazari khurasgani, Z. (2011). Determination and comparison of the organochlorine pesticide residue levels among benni fish of shadegan, mahshahr and susangerd cities, khuzestan province in Iran. Jondishaporur journal of natural pharmaceutical products, 6, 24-31.

Coke, L., Karakaya, A. E., \& Afkham, B. L. (1999). Organochlorine pestiicde contaminants in human milks samples collected in Tabriz (Iran). Bulletin Environmental Toxicology, 63, 44-45. 
C.S. QU, W., Chen, J. BI. L., \& Haung, F. Y. LI. (2010). Ecological risk assessment of pesticide residues in Taihu lake wetland, China. Ecological modelling. http://dx.doi.org/10.1016/j ecol model.2010.07.014

Davodi, M., Esmaili-sari, A., \& Bahramifarr, N. (2010). Concentration of polychlorinated biphenyls and organochlorine pesticides in some edible fish species from the Shadegan marshes (Iran). Ecotoxicology And Environmental Saftey, 7, 2-3. http://dx.doi.org/10.1016/j.ecoenv.2010.07.045

Hela, D., \& Albanis, T. (1998). Pesticide determination in estuarine and marine sediments, using gas chromatography with FTD and MSD. MSD. Fresenius Environmental Bulletin, 7, 704-709.

Hela, D. G., Lambropoulou, D. A., Konstantinu, I. K., \& Albanis, T. A. (2005). Environmental monitoring and ecological risk assessment for pesticide contamination and effects in Lake Pamotives, northwestern Greece. Environmental Toxicology and Chemistry, 24, 1548-1556. http://dx.doi.org/10.1897/04-455R.1

Hosseini, S. V., Behrooz, R. D., Esmaili-sari, A., Bahramifar, N., Hosseini, S. M., Tahergorabi, R., \& Hosseini, S. F., Feas, X. (2008). Contamination by organochlorine compound in the edible tissue of four sturgeon species from the caspian sea (Iran). Chemospher, 73, 972-979.

Lotfi, A., Savari, A., Behrouzi rad, B., Ghaffari, H., \& Kavousi, K. (2002). Shadegan wetland environmental management project, report 2, 76, 44-48.

Munn, D. M., \& Gilliom, R. J. (2001). Pesticide toxicity index for fresh water aquatic organisms, U.S. geological survey, water resources report.

PAN pesticide database, pesticide action network, North America. (2010). [Online] Available: www.pesticideinfo.org.

Sanchez-Bayo, F., Baskaran, S., \& Kennedy, I. R. (2002). Ecological relative risk (ECORR): another approach for risk assessment of pesticides in agriculture. Agriculture Ecosystem Environment, 91, 37-57. http://dx.doi.org/10.1584/jpestics.27.425

Solomon, K. R., \& Sibley, P. (2002). New concepts in ecological risk assessment: where do we go from here? Marine Pollution Bulletin, 44, 279-285. http://dx.doi.org/10.1016/S0025-326X(01)00252-1

Steen, R. J. C. A., Leonards, P. E. G., Brinkman, U. A. T., Barceló, D., Tronczinski, J., Albinis, T. A., \& Confino, W. P. (1999). Ecological risk assessment of agrochemicals in European estuaries. Environmental Toxicology and Chemistry, 18, 1574-1581.

U.S.environmental protection agency. (1998). Guidelines for ecological risk assessment .U.S environmental protection agency, Washington, D.C, EPA/630/R-95/002F.

Van straalen, N. M., \& Denneman, C. A. J. (1998). Ecotoxicological evaluation of soil quality criteria. Ecotoxicology And Environmental Saftey, 18, 241-251.

Wang, B., Y. U, G., Huang, J., \& HU, H. Y. (2008). Development of species sensitivity distributions and estimation of $\mathrm{HC}_{5}$ of organochlorine pesticides with five statistical approaches. Ecotoxicology, 17, 716-724. http://dx.doi.org/10.1007/s10646-008-0220-2

Table 1. Concentration (ng/L) of pesticides residues in water of Shadegan wetland

\begin{tabular}{|c|c|c|c|c|}
\hline & DDT & Lindane & Aldrin/Dieldrin & Ametryn \\
\hline May,2010 & 35.6 & 16 & 3.1 & 1.8 \\
\hline September,2010 & 5.6 & 11.3 & 8.5 & 2 \\
\hline November,2010 & 173 & 761 & 744 & 426 \\
\hline Total mean value & 98.31 & 263 & 252 & 191.2 \\
\hline
\end{tabular}


Table 2. Selected toxicant reference values $(\mu \mathrm{g} / \mathrm{L})$ for different organisms in Shadegan wetland

\begin{tabular}{|c|c|c|c|c|c|c|c|c|c|}
\hline \multirow[t]{3}{*}{ Pesticides } & \multicolumn{2}{|c|}{ phytoplankton } & zooplankton & \multicolumn{2}{|c|}{ invertebrate } & \multirow{2}{*}{$\begin{array}{c}\text { insect } \\
\text { chironomus } \\
\text { sp. }\end{array}$} & \multicolumn{3}{|c|}{ fish } \\
\hline & $\begin{array}{c}\text { Green } \\
\text { algae }\end{array}$ & $\begin{array}{c}\text { Blue-green } \\
\text { algae }\end{array}$ & $\begin{array}{c}\text { Daphnia } \\
\text { pulex }\end{array}$ & Oligochaeta & $\begin{array}{l}\text { Tubifex } \\
\text { tubifex }\end{array}$ & & $\begin{array}{c}\text { B. } \\
\text { grypus }\end{array}$ & $\begin{array}{c}\text { B. } \\
\text { Sharpeyi }\end{array}$ & $\begin{array}{c}B . \\
\text { Luteus }\end{array}$ \\
\hline & $\begin{array}{c}\left(\mathrm{LC}_{50}\right) \\
(7-14 \mathrm{~d})\end{array}$ & $\begin{array}{c}\left(\mathrm{LC}_{50}\right) \\
(7-14 \mathrm{~d})\end{array}$ & $\begin{array}{l}\left(\mathrm{LC}_{50}\right) \\
(48 \mathrm{~h})\end{array}$ & $\begin{array}{c}\left(\mathrm{LC}_{50}\right. \\
(48-96 \mathrm{~h})\end{array}$ & $\begin{array}{c}\left(\mathrm{LC}_{50}\right) \\
(48-96 \mathrm{~h})\end{array}$ & $\begin{array}{c}\left(\mathrm{LC}_{50}\right) \\
(24-48 \mathrm{~h})\end{array}$ & $\begin{array}{l}\left(\mathrm{LC}_{50}\right) \\
(48 \mathrm{~h})\end{array}$ & $\begin{array}{l}\left(\mathrm{LC}_{50}\right) \\
(48 \mathrm{~h})\end{array}$ & $\begin{array}{l}\left(\mathrm{LC}_{50}\right) \\
(48 \mathrm{~h})\end{array}$ \\
\hline DDT & 8500 & 22000 & 105 & 130 & 4000 & 65 & 410 & 105 & 345 \\
\hline Aldrin & 20000 & 15000 & 28 & - & 6710 & 280 & 0.05 & - & - \\
\hline Dieldrin & 20000 & 1000 & 251 & - & - & 560 & - & - & - \\
\hline Ametryn & - & - & 40000 & - & - & - & 2500 & 2500 & 2500 \\
\hline Lindane & 2500 & - & 3800 & 5660 & 3900 & 41.4 & 105 & 76 & 320 \\
\hline
\end{tabular}

Table 3. Summary of $\mathrm{HC}_{5}$ calculations for the pesticides in the Shadegan wetland

\begin{tabular}{|c|c|c|c|c|c|}
\hline Pesticides & $\mathrm{x}_{\mathrm{m}}$ & $\mathrm{s}_{\mathrm{m}}(\mu \mathrm{g} / \mathrm{L})$ & $\mathrm{m}$ & $\mathrm{k}_{\mathrm{L}}$ & $\mathrm{HC}_{5}$ \\
\hline DDT & 6.38 & 4.67 & 9 & 1.75 & 0.1665 \\
\hline Lindane & 6.42 & 4.11 & 8 & 1.76 & 0.9218 \\
\hline Aldrin & 5.71 & 24.74 & 6 & 1.81 & 1.077 \\
\hline Dieldrin & 7.16 & 3.65 & 4 & 1.92 & 1.16 \\
\hline Ametryn & 8.13 & 2.11 & 4 & 1.92 & 59.07 \\
\hline
\end{tabular}

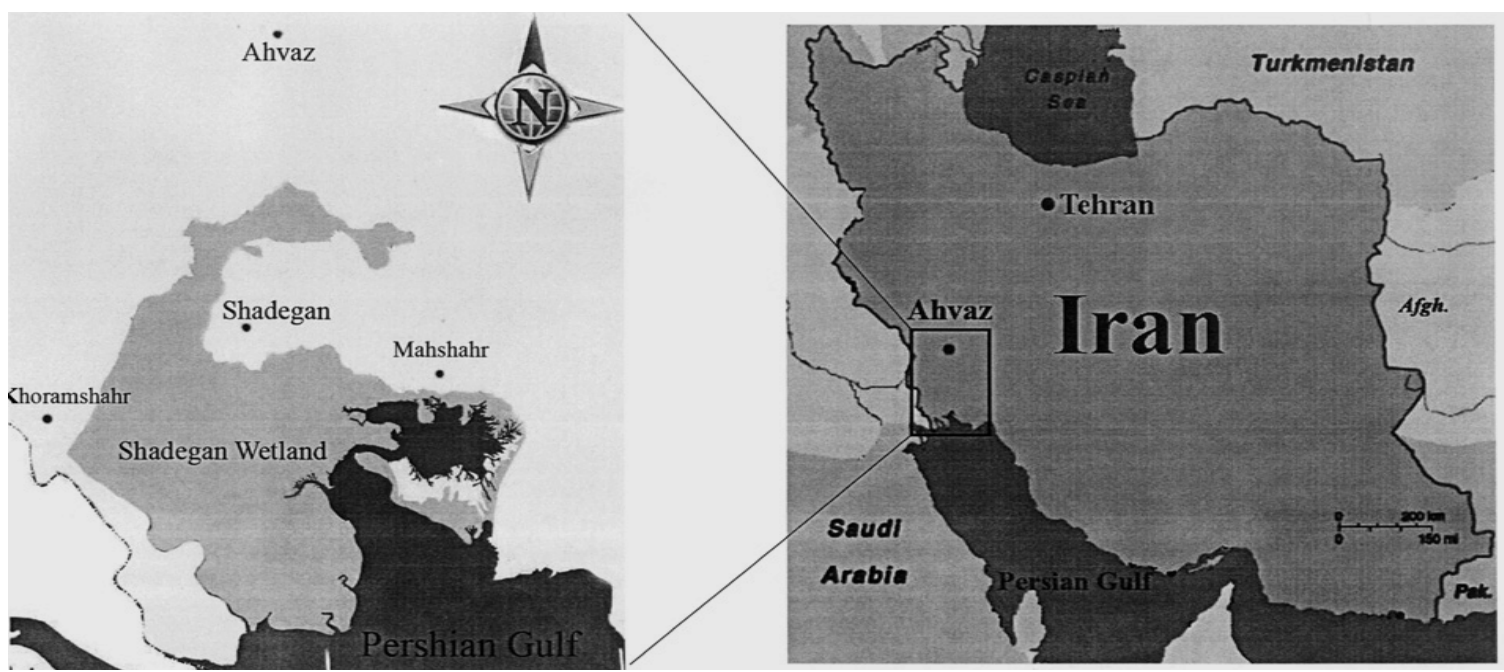

Figure 1. Geographical Location of Shadegan Marshes, Khuzestan, Southwest, Iran

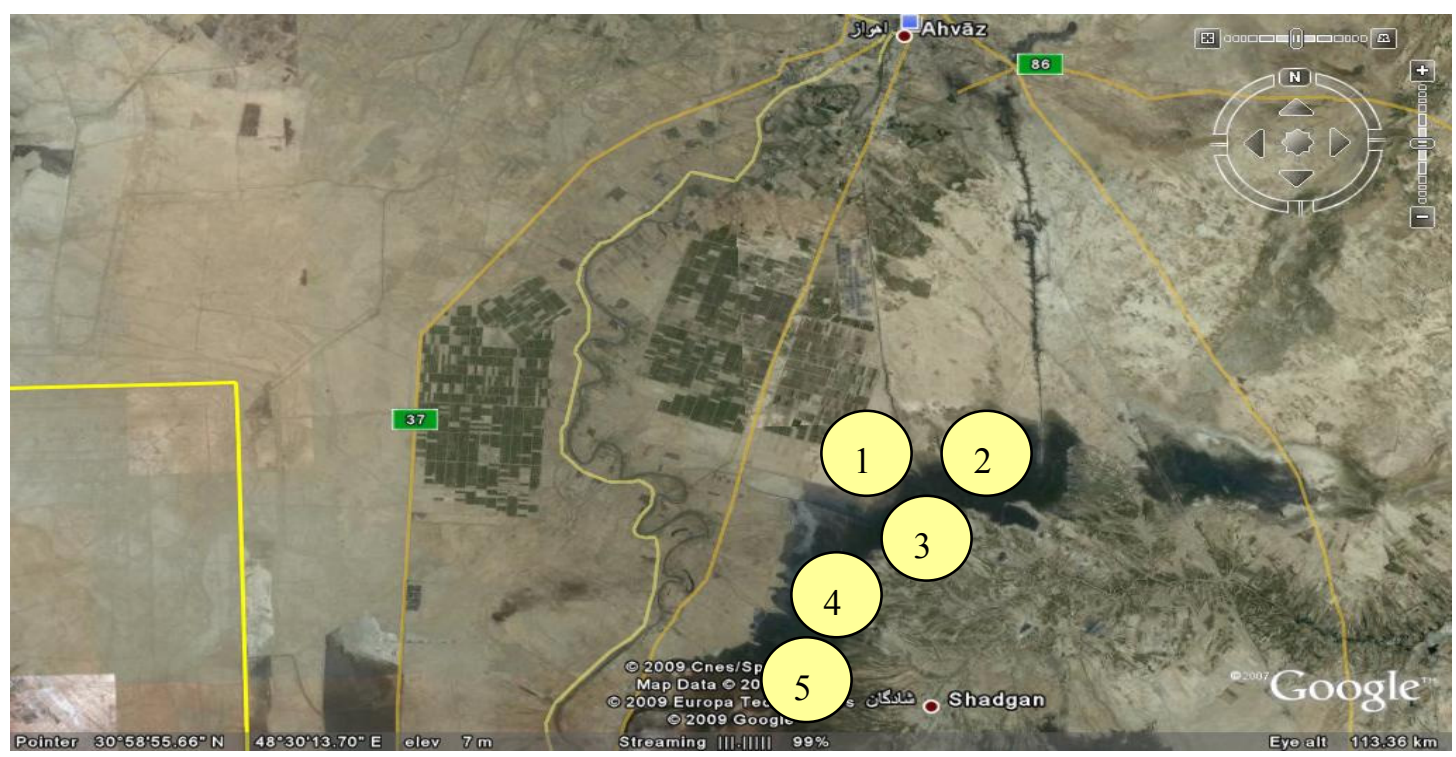

Figure 2. Sampling in Shadegan Wetland, Khuzestan Province, Iran 


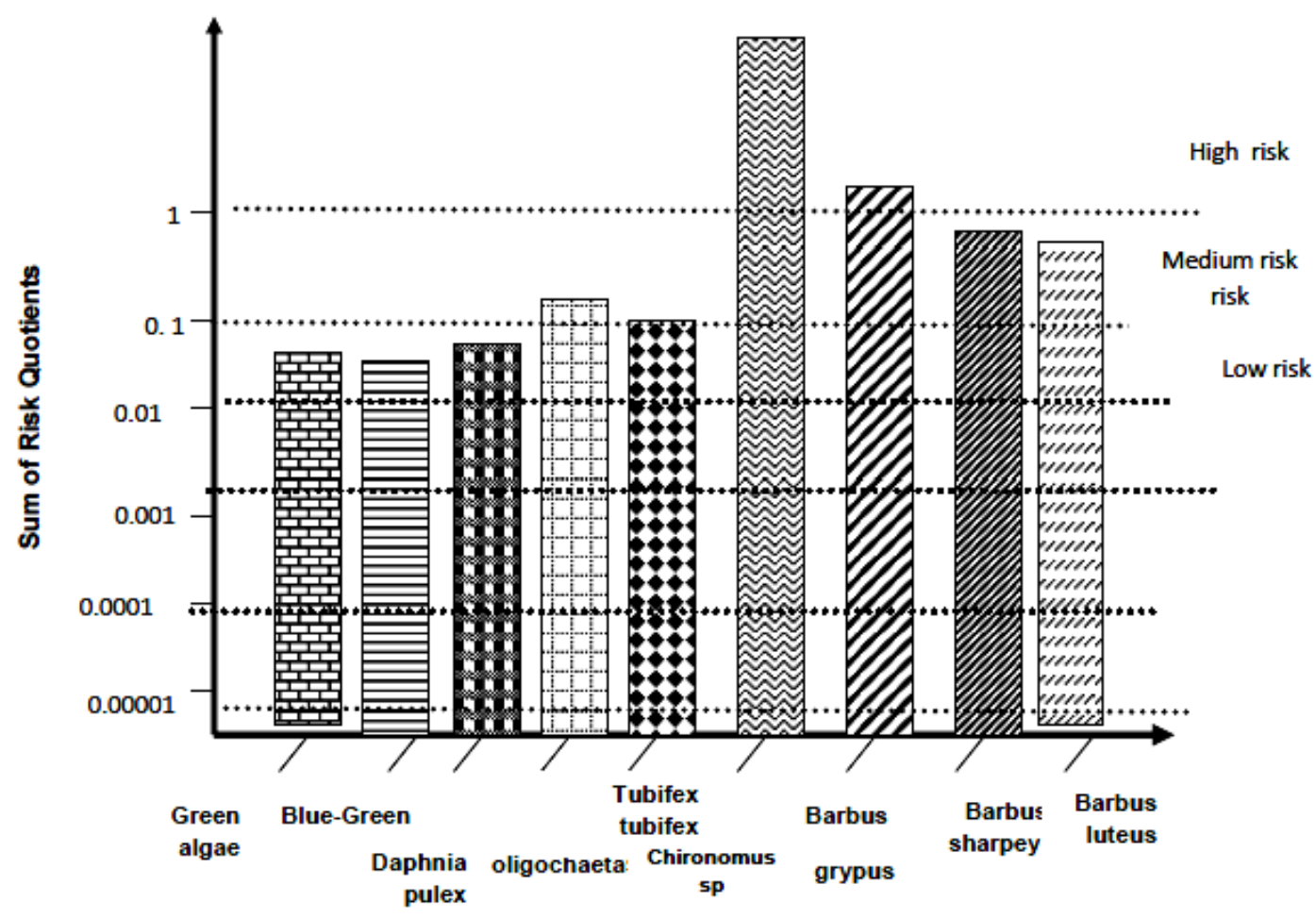

Figure 3. Combined ecological risks based on RQ method

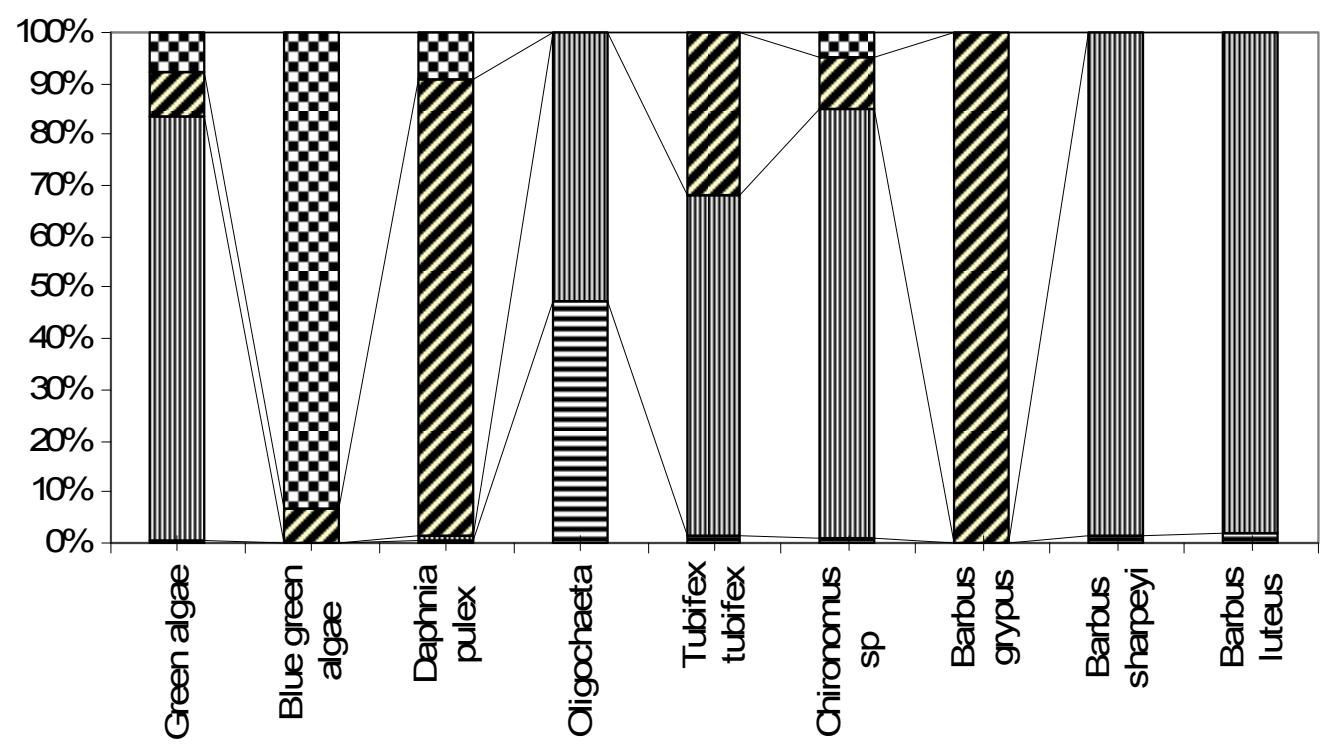

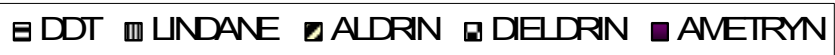

Figure 4. The contribution of detected pesticides in total ecological risk 


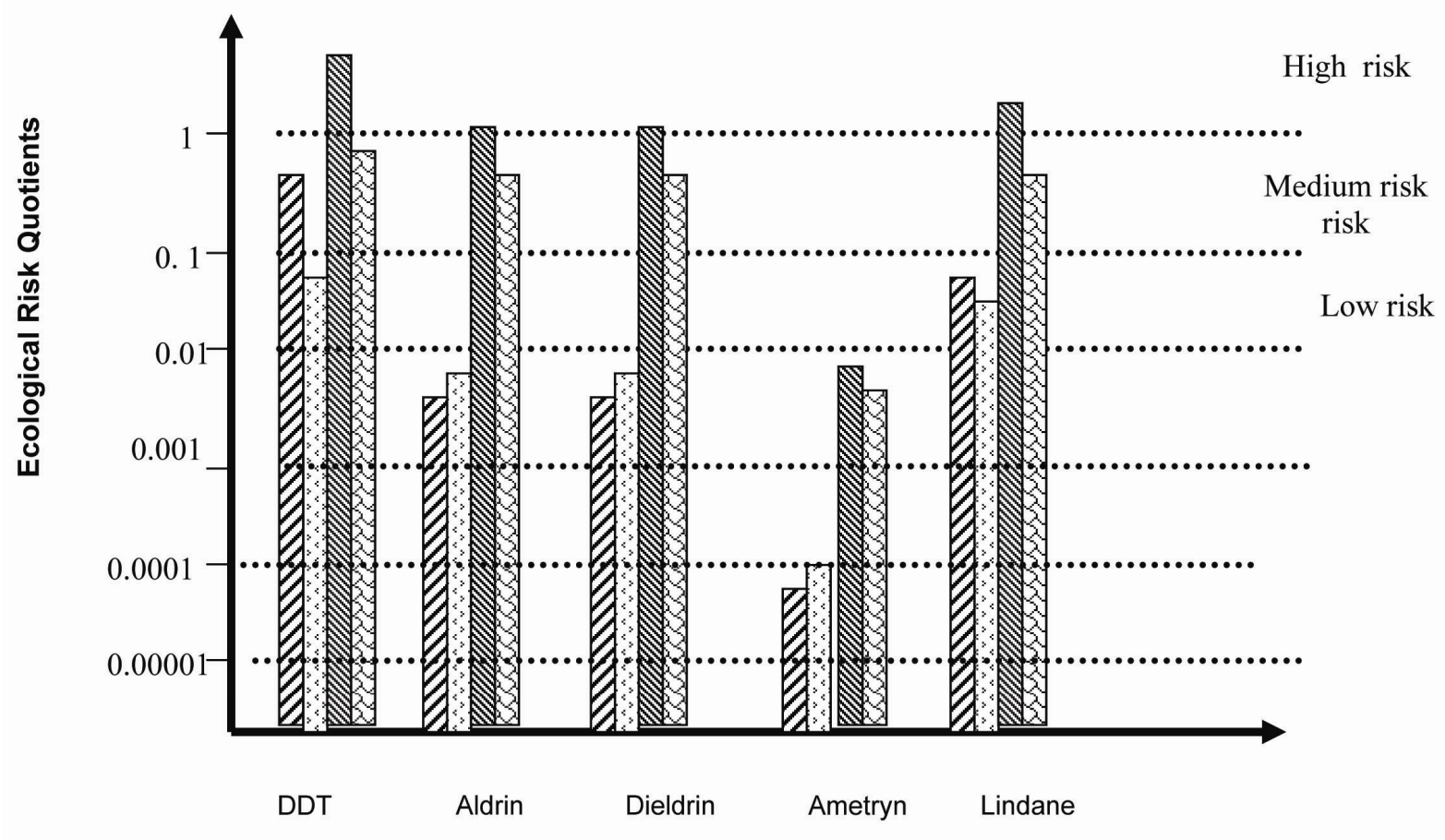

Z May, 2010 September, $2010 \geqq$ November, $2010 \square$ mean value

Figure 5. Combined ecological risks of pesticides based on $\mathrm{HC}_{5}$ data

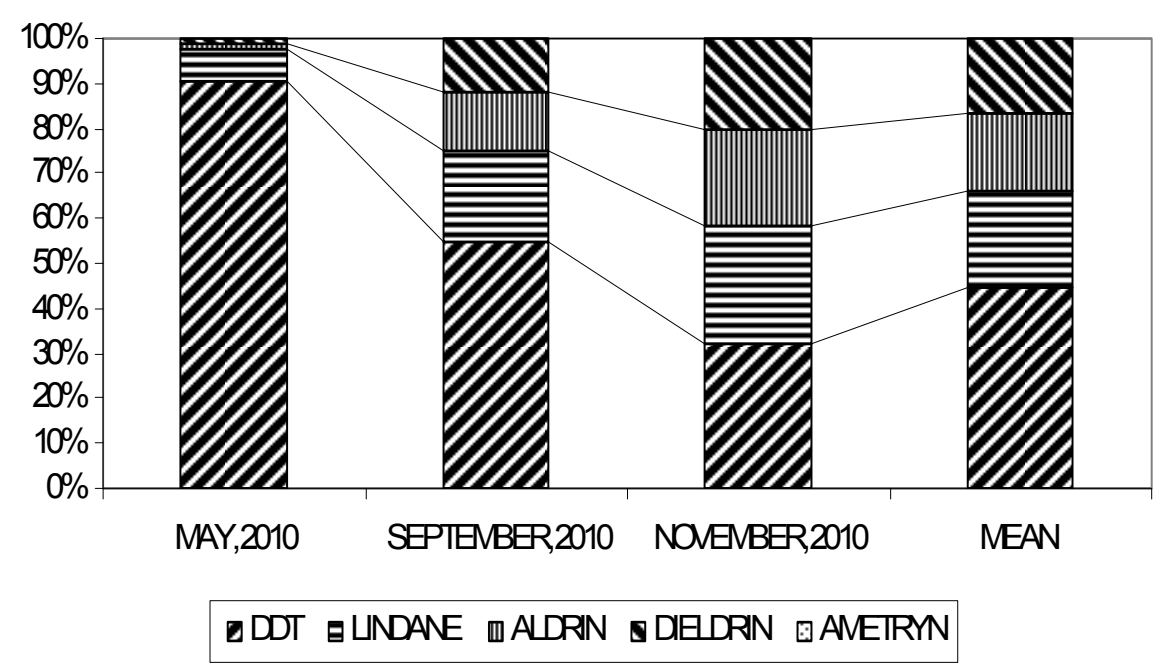

Figure 6. Temporal changes of proportion of each pesticide to the combine ecological risk 